\title{
Ion Mobility-Mass Spectrometry Study of Folded Ubiquitin Conformers Induced By Treatment with cis- $\left[\mathrm{Pd}(\mathrm{en})\left(\mathrm{H}_{2} \mathrm{O}\right)_{2}\right]^{2+}$
}

\author{
Virginia G. Giganti, Sriramu Kundoor, W. Alex Best, Laurence A. Angel \\ Department of Chemistry, Texas A\&M University-Commerce, Texas, USA
}

\begin{abstract}
Ion mobility-mass spectrometry is used to study the new conformers of bovine ubiquitin $(\mathrm{Ub})$ and the palladium(II) binding sites after the incubation with cis-[Pd(en) $\left.\left(\mathrm{H}_{2} \mathrm{O}\right)_{2}\right]^{2+}$ where en = ethylenediamine. Palladium(II) complexes are potentially useful proteomic reagents because they selectively bind to the side groups of methionine and histidine and hydrolytically cleave the peptide bond. Incubating $1.0 \mathrm{mM}$ solution of $\mathrm{Ub}$ with 10.0 molar excess of cis-[ $\left.\mathrm{Pd}(\mathrm{en})\left(\mathrm{H}_{2} \mathrm{O}\right)_{2}\right]^{2+}$ results with one to four $\mathrm{Pd}^{2+}$ or $\mathrm{Pd}(\mathrm{en})^{2+}$ being attached to intact $\mathrm{Ub}$ and two conformer families at each of the $4+$ to $11+$ charge states. The $4+$ and $5+$ species exhibit a compact form, which is also observed in untreated $\mathrm{Ub}$, and a new highly folded conformer. The $6+$ to $10+$ exhibit an elongated form, also observed in $\mathrm{Ub}$, and a new partially folded conformer. The new conformers are shown to be more stable if they contain at least one $\mathrm{Pd}^{2+}$, rather than all $\mathrm{Pd}(\mathrm{en})^{2+}$. IM-MS/ MS of $\left[\mathrm{UbPd}_{2} \mathrm{en}+5 \mathrm{H}\right]^{9+}$ shows that both the partially folded and elongated conformers first lose the en ligand, followed by dissociating into product ions that indicate that Met1, Glu51/Asp52, His68, and Glu16 are binding sites for $\mathrm{Pd}^{2+}$. These results suggest that $\mathrm{Pd}^{2+}$ is simultaneously binding to multiple side groups across different regions of $\mathrm{Ub}$. This type of sequestering of $\mathrm{Pd}^{2+}$ probably reduces the efficiency of $\mathrm{Pd}^{2+}$ ions to selectively cleave $\mathrm{Ub}$ because it prevents $\mathrm{Pd}^{2+}$ anchoring to only Met or His and to an adjacent backbone amide nitrogen and forming the "activated complex" necessary for specific peptide bond cleavage.
\end{abstract}

Key words: Ion mobility, Ubiquitin conformers, Proteomic reagents, $\mathrm{Pd}(\mathrm{II})$ complexes, Mass spectrometry

\section{Introduction}

$\mathrm{T}$ he folding of proteins into specific three-dimensional (3D) structures is one of the supreme feats of molecular self-assembly. Failure of proteins to fold properly or remain correctly folded, however, can cause of a variety of pathologic conditions including neurodegenerative and

Electronic supplementary material The online version of this article (doi:10.1007/s13361-010-0044-1) contains supplementary material, which is available to authorized users.

Correspondence to: Laurence A. Angel; e-mail: laurence_angel@tamucommerce.edu cardiovascular diseases $[1,2]$. Ubiquitin $(\mathrm{Ub})$ is a relatively small 76 residue protein with an isotopic mass of $8559 \mathrm{u}$ and functions as a regulatory protein through post-translational conjugation to target proteins. A prominent role of $\mathrm{Ub}$ is labeling proteins designated for destruction through the proteasome [3]. The proteolysis pathway is important for both the regulation of cellular processes, where proteins are recycled after their function has been completed, and for "quality-control" where misfolded or wrongly sequenced proteins are removed [2].

The ability of an instrumental technique to differentiate between the native and non-native conformers of a protein is essential for understanding healthy and diseased states. Ion mobility-mass spectrometry (IM-MS) allows the recognition 
of different charge states and conformers of a protein by consecutively measuring their mass-to-charge ratios $(\mathrm{m} / \mathrm{z})$ and drift times $[4,5]$. The drift time is dependent on the protein's mobility through a gas-filled cell, which is dependent on the physical shape or collision cross-section of the protein. Integration of traveling wave (T-wave) ion-guide technology with quadrupole and orthogonal time-of-flight mass spectrometry (Q-TOF) allows for a versatile set of ion mobility and collision-induced dissociation (CID) experiments to be performed [6]. Previous studies using T-wave technology include the monitoring of the unfolding of amyloidogenic protein $\beta_{2}$-microglobulin [7], the collisional activation of protein complexes $[8,9]$, and the measurement of the collision cross-section of proteins, peptides and DNA [10-14].

Palladium(II) complexes, such as cis- $\left[\mathrm{Pd}(\mathrm{en})\left(\mathrm{H}_{2} \mathrm{O}\right)_{2}\right]^{2+}$, where en $=$ ethylenediamine, are potentially useful proteomic reagents because they selectively bind to the heteroatoms in the side groups of methionine (sulfur) and histidine (nitrogen) [15]. Moreover, under acidic conditions and elevated temperatures ( $\mathrm{pH} 2.5, \sim 60{ }^{\circ} \mathrm{C}$ ) $\mathrm{Pd}$ (II) typically hydrolytically cleaves the protein or peptide two amide bonds upstream (towards the N-terminal) from the Met or His anchoring site $[15,16]$. The potential applications of $\mathrm{Pd}$ (II) complexes for proteomics include purification strategies by metal affinity chromatography, quantitative analysis of complex protein mixtures [17], and as hydrolysis reagents for cleaving proteins into peptide fragments for MS/MS analysis [15]. Moreover, there is a need to develop a new robust technique for targeting only membrane surface proteins. An inventory of the molecular components present on the outer surface of cell membranes will be a major breakthrough and allow the development of therapeutic drugs to be delivered to specifically targeted cell types such as tumor cells. Membrane proteins, however, are generally insoluble in aqueous buffers, and relatively high concentrations of detergents are needed to keep them soluble. Despite their selectivity and catalytic efficiency, proteolytic enzymes (proteases) such as trypsin are imperfect proteomic agents for membrane proteins because the proteases themselves denature in the presence of the detergents. Pd(II) complexes offer an alternative to proteolytic enzymes because their hydrolysis activity is not affected by the presence of detergents [Angel, L. A.; Miskevich, F.; Kostić, N. M., submitted]. However, most of the studies of Pd(II) complexes have been undertaken with small peptides and there are limited studies investigating the effect that the folded 3D structure of a protein has on the accessibility, binding, and hydrolysis reactions [18-20]. In the past, it has been assumed that the protein has denatured in the weakly acidic solution [20].

The sequence of $\mathrm{Ub}$ from bovine has two potential, Met1 and His68, anchoring sites for $\mathrm{Pd}(\mathrm{II})$. The Met1 site is the first in the sequence and also contains the amino terminal.

MQIFVKTLTG KTITLEVEPS DTIENVKAKI QDKEGIPPDQ QRLIFAGKQL EDGRTLSDYN IQKESTLHLV LRLRGG.
The amino terminal is also a potential Pd(II) binding site and the interplay of the N-terminus with His and Met has been previously studied [20].

A study of $\mathrm{Cu}$ (II) binding to $\mathrm{Ub}$ in solution established that the preferred anchoring site is the N-terminus of Met1 followed by the His68 site [21]. On anchoring to Met1 the $\mathrm{Cu}$ (II) also binds to three oxygen donor ligands to complete a tetragonal binding geometry. Potential oxygen sites were identified as Met1 and Val17 (carbonyl groups), and Glu16 and Glu18 (carboxylate groups) [21]. The $\mathrm{Cu}$ (II) study concluded that the lack of additional donor atoms near His68 made it a less preferred anchoring site than the Met1 site. The binding of $\mathrm{Cu}(\mathrm{II})$ to the N-terminus may also destabilize $\mathrm{Ub}$ by interfering with two key hydrogen bonds between the $\mathrm{N}$-terminus and the $\mathrm{CO}$ of Val17, and the sulfur atom of Met1 and the amide NH of Lys63 [21, 22]. A further X-ray crystallography study of human Ub with $\mathrm{Zn}(\mathrm{II}), \mathrm{Cd}(\mathrm{II})$, or $\mathrm{Hg}(\mathrm{II})$ determined the preferred anchoring sites in order were His68, Met1/Glu16, and Glu18 [23]. All the trials to crystallize $\mathrm{Cu}$ (II) with $\mathrm{Ub}$ were unsuccessful, which was attributed to $\mathrm{Cu}(\mathrm{II})$ destabilizing the $\mathrm{Ub}$ structure and hampering crystallization.

The conformers, collision cross-sections, and the gasphase unfolding transitions of $\mathrm{Ub}$ have been previously reported using conventional IM-MS techniques [24-29], and at native $\mathrm{pH} 7$ conditions using T-wave IM-MS [10]. Two previous reports, using high-field asymmetric waveform ion mobility spectrometry (FAIMS) have also studied the collision-cross sections [30] and effect of conformations on electron capture dissociation of $\mathrm{Ub}$ [31]. In this paper, we show that new folded conformations of $\mathrm{Ub}$ result after the incubation of $\mathrm{Ub}$ with $c i s-\left[\mathrm{Pd}(\mathrm{en})\left(\mathrm{H}_{2} \mathrm{O}\right)_{2}\right]^{2+}$. A previous ESIMS/MS study by Zhu and coworkers [32] effectively assigned the binding sites of $\mathrm{Cu}(\mathrm{II})$ and $\mathrm{Pt}(\mathrm{II})$ complexes towards the oxidized insulin $\mathrm{B}$ chain peptide. Here we present IM-MS/MS results that identify $\mathrm{Pd}^{2+}$ and $\mathrm{Pd}(\mathrm{en})^{2+}$ binding sites on the conformers and charge states of $\mathrm{Ub}$ and investigates whether there is a correlation between the type of binding and the conformers of $\mathrm{Ub}$.

\section{Experimental}

\section{Chemicals}

Ub from bovine erythrocytes with 98\% (SDS-PAGE) purity and cis-[Pd(en) $\left.\mathrm{Cl}_{2}\right]$ with $99 \%$ purity were purchased from Aldrich. The cis- $\left[\mathrm{Pd}(\mathrm{en})\left(\mathrm{H}_{2} \mathrm{O}\right)_{2}\right]^{2+}$ was obtained by the published method [33-35]. HPLC grade acetic acid (glacial) and acetonitrile were purchased from Fisher Scientific.

\section{Preparation of Palladiated $\mathrm{Ub}$}

The aqueous palladiated $\mathrm{Ub}(\mathrm{Pd}-\mathrm{Ub})$ sample was prepared by incubating $1.0 \mathrm{mM}$ solution of $\mathrm{Ub}$ with 10.0 molar excess of $c i s-\left[\mathrm{Pd}(\mathrm{en})\left(\mathrm{H}_{2} \mathrm{O}\right)_{2}\right]^{2+}$. The $\mathrm{pH}$ of the solution was adjusted with acetic acid to $\mathrm{pH}$ 2.5. The solution was then incubated 
at room temperature for $1 \mathrm{~h}$ and stored at $-20{ }^{\circ} \mathrm{C}$. The sample was analyzed over several months and showed a small increase in the higher palladiated species with lower en over this time. For IM-MS analysis, the Pd-Ub sample was diluted to $2 \times 10^{-5} \mathrm{M}$ with $\mathrm{H}_{2} \mathrm{O}$, giving a final $\mathrm{pH} 3$. The untreated $\mathrm{Ub}$ was prepared in $\mathrm{H}_{2} \mathrm{O}$ solvent at $2 \times 10^{-5} \mathrm{M}$ with $1.0 \%$ vol acetic acid, giving a solution of $\mathrm{pH} 3$.

\section{Waters Synapt HDMS}

The sample was directly infused into the electrospray ionization (ESI) source of a Synapt HDMS (Waters UK Ltd., Manchester, UK) [6] using a flow rate of $10-30 \mu \mathrm{L} /$ min. The hybrid instrument has a quadrupole-ion mobilityorthogonal time-of-flight configuration. Typical conditions in the source region were $3.0 \mathrm{kV}$ capillary voltage, $40 \mathrm{~V}$ sampling cone, $4.0 \mathrm{~V}$ extraction cone gas flow of $100 \mathrm{~mL} /$ $\min \mathrm{N}_{2}$, and a desolvation gas flow of $500 \mathrm{~mL} / \mathrm{min} \mathrm{N}_{2}$. Source fragmentation of $\mathrm{Ub}$ was observed at higher sampling and extraction cone voltages. The conformations of Pd-Ub were also affected by the sampling and extraction cone voltages and are shown in the Results section. The source and desolvation temperatures were set at $80^{\circ} \mathrm{C}$ and $100{ }^{\circ} \mathrm{C}$, respectively, and the source traveling wave, which is the region between the ESI and the quadrupole analyzer, was maintained at 2.15 mbar. The ion mobility (IM) cell is part of the interaction region that comprises of three traveling wave (T-wave) ion guides with geometry of trap T-wave/IM $\mathrm{T}$-wave/transfer T-wave. The trap T-wave functions as both a collision cell for CID experiments and as a storage cell for gating ions into the IM T-wave ion guide. The IM T-wave operates by the superimposition of traveling wave voltages on a radially-confining rf field [6]. For a typical experiment, the traveling wave height was linearly ramped from 5 to $9 \mathrm{~V}$ and the wave velocity from 190 to $400 \mathrm{~m} / \mathrm{s}$ for every pass along the IM T-wave ion guide. Pressure inside the IM cell was $0.6 \mathrm{mbar}$ supplied by $\mathrm{N}_{2}$ flow of $25 \mathrm{~mL} / \mathrm{min}$. Collisions between analyte ions and $\mathrm{N}_{2}$ cause the less mobile ions to have longer drift times because they are less effectively pushed through the IM T-wave ion guide by the traveling waves. The transfer $\mathrm{T}$-wave was operated with a constant $248 \mathrm{~m} / \mathrm{s}$ wave velocity and $5 \mathrm{~V}$ wave height to maintain the ion mobility separation from the IM T-wave cell. The transfer T-wave can also be used for CID experiments. Both trap and the transfer ion guides were operated at pressures of $2.7 \times 10^{-2}$ mbar supplied by a $1.5 \mathrm{~mL} / \mathrm{min}$ argon flow. For IM-MS/MS experiments, the parent ion is resolved by the quadrupole mass analyzer and voltages applied to either the trap or transfer $\mathrm{T}$-wave ion guides control the lab-frame collision energy (CE). The trap is the default collision cell and allows for both the parent and product ions to be drift time separated by the ion mobility T-wave cell. The transfer cell occurs after the ion mobility cell and CID experiments using the transfer cell result in product ions being timealigned with their parent ion.

\section{Estimated Collision Cross-Sections}

To estimate the collision cross-sections of Pd-Ub a calibration procedure [10] was used with the published cross-sections from the Clemmer group [26] for the compact and elongated conformers of $\mathrm{Ub}$. Our results showed the compact and elongated $\mathrm{Ub}$ conformer groups exhibited different calibration slopes. To estimate cross-sections for the $6+$ to $10+\mathrm{Pd}-\mathrm{Ub}$ conformers, the drift times from elongated $6+$ to $11+\mathrm{Ub}$ conformers from a denaturing solution were used and for the cross-sections of the $4+$ and $5+\mathrm{Pd}-\mathrm{Ub}$ conformers the compact $4+$ and $5+$ Ub drift times. The cross sections of the new 9+ and $10+$ conformers were within $5 \%$ of the lowest cross section on the calibration curve. Error analysis of the Pd-Ub crosssections using calibration curves based on drift time measurements of $\mathrm{Ub}$ from different $\mathrm{pH}$ and denaturing solutions and comparison of the drift time slopes of the new, compact and the elongated conformers support that these cross-sections are reasonable estimates.

\section{Results and Discussion}

\section{$I M-M S$ Analysis of Ub and Pd-Ub Conformers}

IM-MS driftscope plots showing the drift times of the different $\mathrm{m} / \mathrm{z}$ species of $\mathrm{Ub}$ and $\mathrm{Pd}-\mathrm{Ub}$ using the same experimental conditions are shown in Figure 1. All species were identified from their isotope patterns using the isotope modeling tool in the MassLynx software and close-ups of extracted drift times and $m / z$ for selected species are shown in the SI. Figure 1a shows the distribution of the charge states and conformations of $\mathrm{Ub}$. The $\left[\mathrm{Ub}_{3}+11 \mathrm{H}\right]^{11+}$ trimer, $\left[\mathrm{Ub}_{2}+7 \mathrm{H}\right]^{7+}$, and $\left[\mathrm{Ub}_{2}+9 \mathrm{H}\right]^{9+}$ dimers are observed as minor species at the high $\mathrm{m} / \mathrm{z}$ region. The monomers of $\mathrm{Ub}$ are labeled $4+$ to $11+$ and fall into two conformer groups previously assigned the compact and elongated forms by comparing their cross-sections, measured by conventional IM-MS, with those calculated for the crystal and near-linear conformations of Ub [24-26]. These groups are shown within the dashed ovals and transverse the driftscope plot because drift times are directly related to the collision crosssection and inversely related to charge [7]. The lower charged monomers $[\mathrm{Ub}+4 \mathrm{H}]^{4+}$ and $[\mathrm{Ub}+5 \mathrm{H}]^{5+}$ are in the compact group. The $[\mathrm{Ub}+6 \mathrm{H}]^{6+}$ species is the most abundant state of $\mathrm{Ub}$ at $\mathrm{pH} 3$, after ESI, and exhibits a broad drift time band that exhibits mainly an elongated conformer of ubiquitin. The higher Ub charge states of $7+$ to $11+$ all have elongated conformations. This behavior is typical of proteins in the gas-phase where the lower charge states are the most compact and the higher charge states are elongated due to increasing Coulombic repulsion inducing the unfolding of the protein. The distribution of Ub conformers as a function of charge observed in this study is very similar to those observed in previous IM-MS studies [10, 24], although two recent studies have shown the $6+$ and $7+$ states in the compact form $[27,28]$ implying the $6+$ and $7+\mathrm{Ub}$ conformers in the present study have undergone gas-phase 

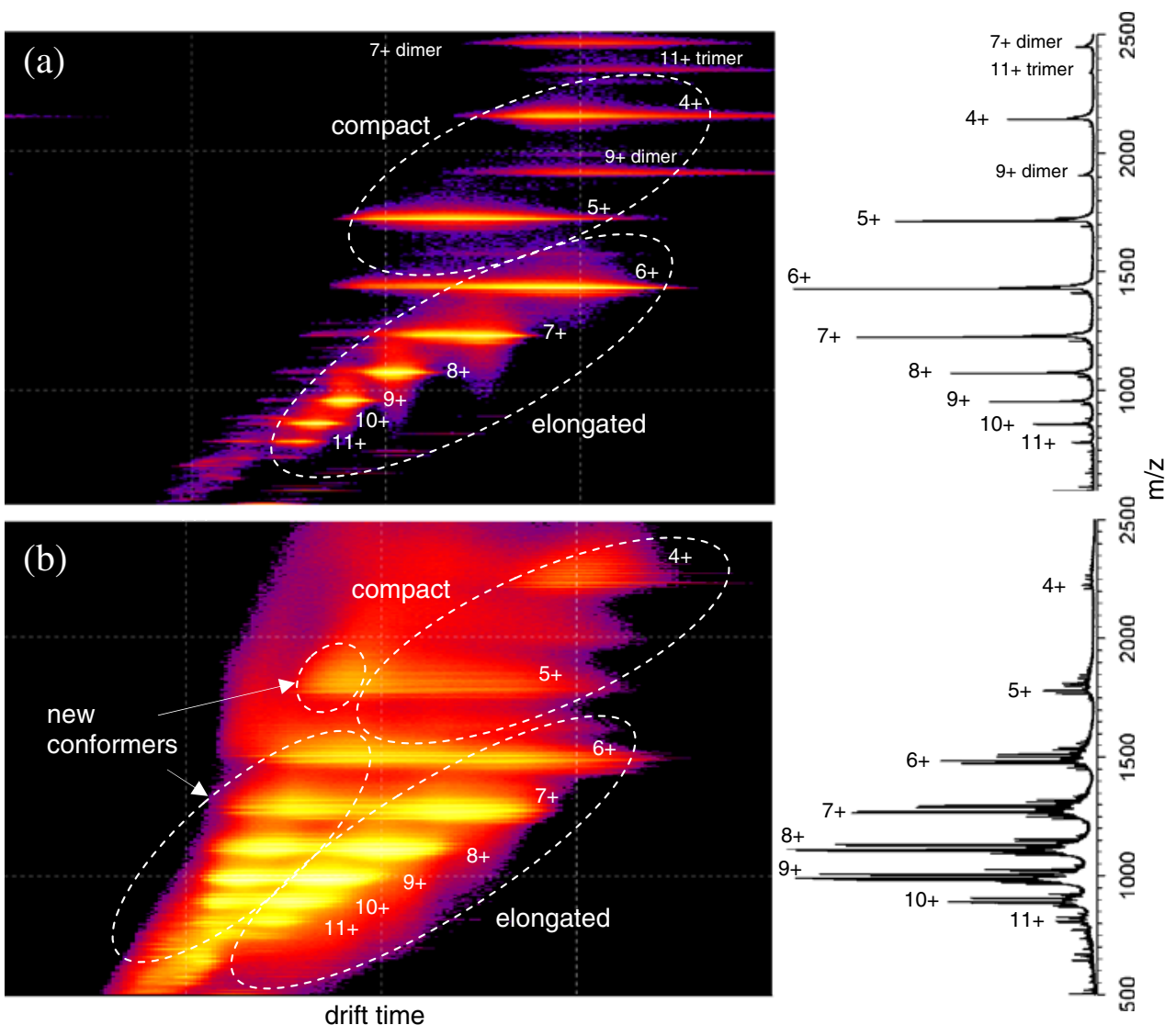

Figure 1. IM-MS driftscope plots showing $\mathrm{m} / \mathrm{z}$ (y-axis) versus drift time (x-axis) of (a) $\mathrm{Ub}$ in $\mathrm{H}_{2} \mathrm{O}$ solvent, $\mathrm{pH}$ 3. (b) $\mathrm{Ub}$ treated with cis- $\left[\mathrm{Pd}(\mathrm{en})\left(\mathrm{H}_{2} \mathrm{O}\right)_{2}\right]^{2+}$ in $\mathrm{H}_{2} \mathrm{O}, \mathrm{pH} 3$

unfolding. However, all the other charge state conformations for $\mathrm{Ub}$ are consistent with other studies.

Figure $1 \mathrm{~b}$ shows the IM-MS of Ub after the addition of cis$\left[\mathrm{Pd}(\mathrm{en})\left(\mathrm{H}_{2} \mathrm{O}\right)_{2}\right]^{2+}$ and shows a similar charge distribution to $\mathrm{Ub}$, although the relative intensity of the $8+$ and $9+$ charge states have increased. Each of the charge states now contains $\operatorname{Pd}^{2+}$ and/or Pden ${ }^{2+}$ attached to $\mathrm{Ub}$ and exhibit a new folded or partially folded conformer. Figure 2 shows a close-up of the Pd$\mathrm{Ub}$ species observed at the 9+ charge state. A similar variety of Pd-Ub species were observed at all the other charge states.

Figure 2 shows there is a small amount of $[\mathrm{Ub}+9 \mathrm{H}]^{9+}$ $(953 \mathrm{~m} / \mathrm{z})$ in the elongated conformer, left after the addition of cis- $\left[\mathrm{Pd}(\mathrm{en})\left(\mathrm{H}_{2} \mathrm{O}\right)_{2}\right]^{2+}$. Most of the Pd-Ub species are observed in both the new and elongated conformations,
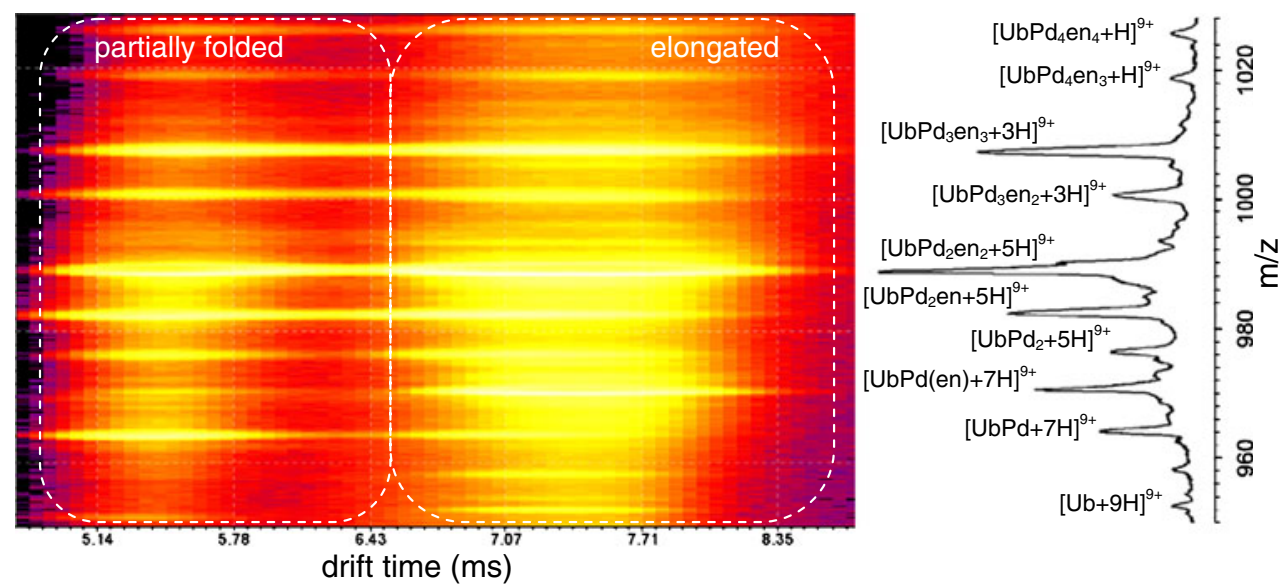

Figure 2. IM-MS driftscope plot showing $\mathrm{m} / \mathrm{z}$ (y-axis) versus drift time (x-axis) of the various palladiated ubiquitin species at the $9+$ charge state 


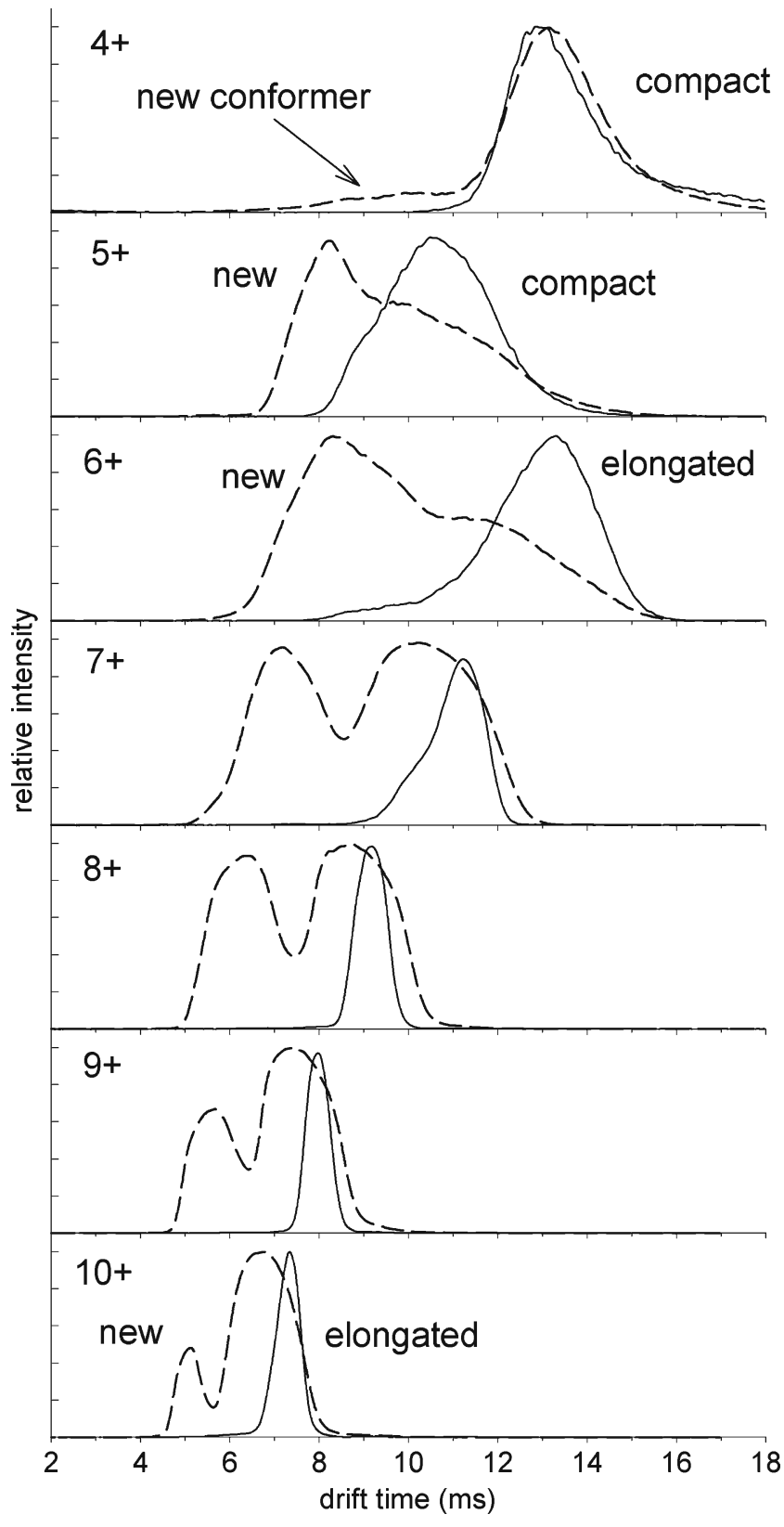

Figure 3. Extracted drift times of $(-)\left[\mathrm{Ub}+9 \mathrm{H}^{+}\right]^{9+}$ and (- - -) $\left[\mathrm{UbPd}_{2} \mathrm{en}_{2}+5 \mathrm{H}^{+}\right]^{9+}$ for the charge states of $4+$ to $10+$ showing that the binding of $\mathrm{Pd}^{2+}$ or $\mathrm{Pd}(\mathrm{en})^{2+}$ is producing these new conformers. For example, $[\mathrm{UbPd}+7 \mathrm{H}]^{9+}(964 \mathrm{~m} / \mathrm{z})$, $\left[\mathrm{UbPd}_{2}+5 \mathrm{H}\right]^{9+}(976 \mathrm{~m} / \mathrm{z}),\left[\mathrm{UbPd}_{2} \mathrm{en}+5 \mathrm{H}\right]^{9+}(982 \mathrm{~m} / \mathrm{z}),[\mathrm{Ub}$ $\left(\mathrm{Pd}_{2} \mathrm{en}_{2}+5 \mathrm{H}\right]^{9+}(989 \mathrm{~m} / \mathrm{z}),\left[\mathrm{UbPd}_{3} \mathrm{en}_{2}+3 \mathrm{H}\right]^{9+}(1001 \mathrm{~m} / \mathrm{z})$, and $\left[\mathrm{UbPd}_{3} \mathrm{en}_{3}+3 \mathrm{H}\right]^{9+}(1007 \mathrm{~m} / \mathrm{z})$ are all observed in both conformers. Only [UbPd(en) $+7 \mathrm{H}]^{9+}(971 \mathrm{~m} / \mathrm{z})$ is predominantly observed in the elongated form. The preferred binding geometry of $\mathrm{Pd}^{2+}$ is square planar and the single $\mathrm{Pd}(\mathrm{en})^{2+}$ in $[\mathrm{UbPd}(\mathrm{en})+7 \mathrm{H}]^{9+}$ has only two available binding sites for $\mathrm{Ub}$. The other Pd-Ub species have a higher total number of possible $\mathrm{Pd}^{2+}$ or $\mathrm{Pd}(\mathrm{en})^{2+}$ binding sites. For example, $\left[\mathrm{UbPd}_{2} \mathrm{en}_{2}+5 \mathrm{H}\right]^{9+}$ has two $\mathrm{Pd}(\mathrm{en})^{2+}$ which can attach to four Ub sites and $\left[\mathrm{UbPd}_{2} \mathrm{en}+5 \mathrm{H}\right]^{9+}$ has a $\mathrm{Pd}^{2+}$ and $\mathrm{Pd}(\mathrm{en})^{2+}$ that can bind to six Ub sites. The relative stability of the new compact conformers was tested by raising the $\mathrm{CE}$ to $30 \mathrm{~V}$ lab (trap T-wave cell) and monitoring the conformers of 9+ Pd-Ub. The species that contained $\mathrm{Pd}^{2+}$ (i.e. $\left[\mathrm{UbPd}_{3} \mathrm{en}_{2}+3 \mathrm{H}\right]^{9+}$, $\left[\mathrm{UbPd}_{2} \mathrm{en}+5 \mathrm{H}\right]^{9+},\left[\mathrm{UbPd}_{2}+5 \mathrm{H}\right]^{9+}$, and $[\mathrm{UbPd}+7 \mathrm{H}]^{9+}$ ) were still observed in the new partially folded conformer, while the species that contained only $\mathrm{Pd}(\mathrm{en})^{2+}$ (i.e. $[\mathrm{UbPd}(\mathrm{en})+7 \mathrm{H}]^{9+}$ $\left[\mathrm{UbPd}_{2} \mathrm{en}_{2}+5 \mathrm{H}\right]^{9+}$ and $\left[\mathrm{UbPd}_{3} \mathrm{en}_{3}+3 \mathrm{H}\right]^{9+}$ were only observed in the elongated conformer.

\section{Comparison of the Conformers of $U b$ and $P d-U b$}

To compare more directly the two conformers of $\mathrm{Ub}$ and $\mathrm{Pd}-$ $\mathrm{Ub}$, the drift times of $\left[\mathrm{UbPd}_{2} \mathrm{en}_{2}+(n-4) \mathrm{H}\right]^{n+}$ and $[\mathrm{Ub}+n \mathrm{H}]^{n+}$ have been extracted from the different charge states of $4+$ to $10+$ and are shown in Figure 3. The collision cross-sections have also been estimated for the new Pd-Ub conformers and are shown in Table 1[10]. Figure 3 shows the drift time distributions of $[\mathrm{Ub}+4 \mathrm{H}]^{4+}$ and $\left[\mathrm{UbPd}_{2} \mathrm{en}_{2}\right]^{4+}$ are similar, with $\left[\mathrm{UbPd}_{2} \mathrm{en}_{2}\right]^{4+}$ also showing a small presence of the new folded conformer group. At the $5+$ state, $\left[\mathrm{UbPd}_{2} \mathrm{en}_{2}+\mathrm{H}\right]^{5+}$ exhibits both the new and compact conformer families, with the new conformer being the principal species, whereas, $[\mathrm{Ub}+5 \mathrm{H}]^{5+}$ remains primarily in the compact form. Table 1 shows the cross-section of the new folded conformer family of $\left[\mathrm{UbPd}_{2} \mathrm{en}_{2}+\mathrm{H}\right]^{5+}$ is $20 \%$ smaller than the cross-section for the compact form. At the $6+$ state, $\left[\mathrm{UbPd}_{2} \mathrm{en}_{2}+2 \mathrm{H}\right]^{6+}$ exhibits two overlapping conformer families and signifies the transition from the compact forms of $4+$ and $5+$ to the elongated conformers of $6+$ to $10+$. The new conformer of

Table 1. Estimated average collision cross-sections $\left(\AA^{2}\right)$ for the $\left[\mathrm{UbPd}_{2} \mathrm{en}_{2}+(n-4) \mathrm{H}^{+}\right]^{n+}$ conformer families

$\left[\mathrm{UbPd}_{2} \mathrm{en}_{2}+(n-4) \mathrm{H}^{+}\right]^{n+}$

\begin{tabular}{ccc}
\hline Charge $(n+)$ & New conformer & Compact $^{\mathrm{a}}$, elongated $^{\mathrm{b}}$ \\
\hline $4+$ & $790 \pm 40$ & $1020 \pm 20^{\mathrm{a}}$ \\
$5+$ & $820 \pm 80$ & $1030 \pm 40^{\mathrm{a}}$ \\
$6+$ & $1120 \pm 20$ & $1370 \pm 40^{\mathrm{b}}$ \\
$7+$ & $1190 \pm 20$ & $1480 \pm 20^{\mathrm{b}}$ \\
$8+$ & $1270 \pm 20$ & $1540 \pm 20^{\mathrm{b}}$ \\
$9+$ & $1330 \pm 20$ & $1560 \pm 20^{\mathrm{b}}$ \\
$10+$ & $1390 \pm 30$ & $1640 \pm 30^{\mathrm{b}}$ \\
\hline
\end{tabular}

Collision cross-sections extrapolated from the collision cross-sections of Ub measured by the Clemmer group [26] 
$\left[\mathrm{UbPd}_{2} \mathrm{en}_{2}+2 \mathrm{H}\right]^{6+}$ has also undergone partial unfolding, with respect to the $5+$ state, as observed by the change in crosssections from $820 \AA$ to $1120 \AA$. The $7+$ to $10+$ states of $\mathrm{Pd}-\mathrm{Ub}$ exhibit both the new partially folded and elongated conformers, while $\mathrm{Ub}$ exhibits only the elongated conformations which show increasingly narrowing drift time distributions as charge increases. Both the new and the elongated conformers of Pd-Ub exhibit a significant shift to shorter drift times when compared to the drift times of elongated $\mathrm{Ub}$. The Pd-Ub drift times are also significantly broader, than those of Ub, indicating a higher number of folded conformers are contributing to both the new and elongated Pd-Ub families.

Figure 1 shows that there is only a small change in the distribution of charge states before and after the attachment of multiple $\mathrm{Pd}^{2+}$ or $\mathrm{Pden}^{2+}$. To conserve charge, each $\mathrm{Pd}^{2+}$ or $\mathrm{Pd}$ $(\mathrm{en})^{2+}$ that binds to $\mathrm{Ub}$ must be replacing on average two $\mathrm{H}^{+}$. $\mathrm{Pd}$ $(\mathrm{en})^{2+}$ or $\mathrm{Pd}^{2+}$ may, however, covalently bind to two or more sites across different folded regions of $\mathrm{Ub}$, helping to maintain a folded structure. Whether the new folded $5+$ or $6+$ conformers are related to the native folded state of $\mathrm{Ub}$ is an interesting question. The native structure of $\mathrm{Ub}$ is highly compact and tightly hydrogen-bonded [22]. A primary Ub binding site for $\mathrm{Pd}^{2+}$ is expected to be Met1. However, in the native structure both the N-terminus and sulfur in the side-group of Met1 are hydrogen-bonded to the carbonyl group of Val1 7 and the amide of Lys63, respectively [22]. It has been suggested that disruption of these key hydrogen-bonds could destabilize the native form of $\mathrm{Ub}[21]$. probably resulting in the new folded $5+$ or $6+$ conformers being molten globules: compact forms of $\mathrm{Ub}$ that do not retain its biological function [4].

\section{Pd-Ub Conformers Dependence on Source Conditions}

The relative intensities of the new, compact and elongated conformers of Pd-Ub were dependent on the ESI source conditions. Figure 4 shows that when the sampling cone and extraction cone voltages in the source region are varied the relative intensities for the conformers change. The sampling cone and extraction cone voltages sample ions from the orthogonal electrospray and focus them into the entrance aperture and heated block of the instrument. The relatively gentle extraction voltages of Figure $4 \mathrm{a}$ favor conserving the new partially folded conformers of the $6+$ to $10+$ states. However, the higher extraction voltages used in Figure $4 \mathrm{~b}$ results in similar intensities for both the new partially folded and elongated conformers. The $4+$ and $5+$ ions are also more intense, at these higher voltages, because of the higher efficiency of extracting these low charge ions from the orthogonal electrospray. In Figure 4c, the use of the highest cone and extraction voltages results in the $6+$ to $9+$ charged species predominantly being observed in the elongated conformer. As source voltages increase, the drift time of the 5+ ion is also shifting to longer drift times and exhibiting unfolding. The ESI source region is close to atmospheric pressure and higher extraction voltages result in higher collision energies between the Pd-Ub ions and ambient air molecules, resulting in the unfolding of Pd-Ub. A study of Pd-Ub at the $8+$ state showed the species still remaining in the new partially folded conformer at the higher extraction voltages were $\left[\mathrm{UbPd}_{2} \mathrm{en}\right.$ $+4 \mathrm{H}]^{8+}$ and $\left[\mathrm{UbPd}_{3} \mathrm{en}_{2}+2 \mathrm{H}\right]^{8+}$. Smith et al [10]. observed the 4 + to $6+$ states of $\mathrm{Ub}$ from a buffered $\mathrm{pH} 7$ solution using the Synapt instrument but with a nano-ESI source. Their smallest measured cross-section for $[\mathrm{Ub}+4 \mathrm{H}]^{4+}$ is $791 \AA$ which corresponds closely to the cross-section of $790 \AA$ for the new folded $\left[\mathrm{UbPd}_{2} \mathrm{en}_{2}\right]^{4+}$ conformer but not to the compact form of $1020 \AA$ which is close to the $1004 \AA$ cross-section for $\left[\mathrm{Ub}+4 \mathrm{H}^{+}\right]^{4+}$ measured by the Clemmer group [27]. In our experiments, changing the cone or extraction voltages did not result in any new folded conformers of $[\mathrm{Ub}+4 \mathrm{H}]^{4+}$. Using solutions with a $\mathrm{pH}$ of 6.5 and 8.5 only reduced the $[\mathrm{Ub}+4 \mathrm{H}]^{4+}$ cross-section by $2 \%$. This disparity may be due to the nano-ESI preferentially retaining a more tightly folded conformer of $[\mathrm{Ub}+4 \mathrm{H}]^{4+}$.

\section{IM-MS/MS Analysis of $\mathrm{Pd}-\mathrm{Ub}$ and Investigating the $P d^{2+}$ Binding Sites}

To try to determine if a specific $\mathrm{Pd}^{2+}$ binding motif is responsible for the new folded conformations, we undertook a series of IM-MS/MS and MS/MS experiments on a range of $\mathrm{Pd}-\mathrm{Ub}$ species at different charge states and collision
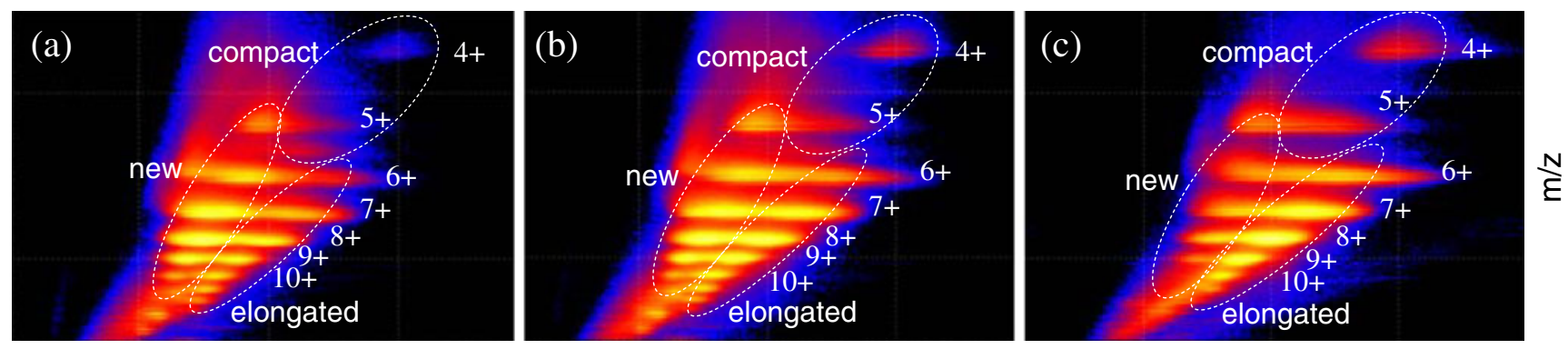

drift time (ms)

Figure 4. IM-MS driftscope plots showing the effect the source conditions of the Synapt HDMS has on the conformers of Ub treated with cis- $\left[\mathrm{Pd}(\mathrm{en})\left(\mathrm{H}_{2} \mathrm{O}\right)_{2}\right]^{2+}$ (a) sampling cone $30.0 \mathrm{~V}$, extraction cone $2.0 \mathrm{~V}$, (b) sampling cone $40.0 \mathrm{~V}$, extraction cone $4.0 \mathrm{~V}$, (c) sampling cone $62.0 \mathrm{~V}$, extraction cone $6.0 \mathrm{~V}$. Capillary voltage $(3.0 \mathrm{kV})$, source temperature $\left(80{ }^{\circ} \mathrm{C}\right)$, and desolvation temperature $\left(100^{\circ} \mathrm{C}\right)$ were all held constant for each experiment 
energies (SI). Generally, the lower charge states needed higher collision energies to fragment but produced similar product ions. Here we focus on the main product ions observed from these studies. At low collision energies, Pd$\mathrm{Ub}$ species that contained $\mathrm{Pd}(\mathrm{en})^{2+}$ dissociate by losing the en ligand. Figure 5 shows a close-up of the IM-MS/MS of the new partially folded and elongated conformers of $\left[\mathrm{UbPd}_{2} \mathrm{en}+5 \mathrm{H}\right]^{9+}$ with $25 \mathrm{~V}$ lab CE applied to the trap Twave cell, resulting in both the parent and daughter ions being separated in the IM cell. The $\left[\mathrm{UbPd}_{2} \mathrm{en}+5 \mathrm{H}\right]^{9+}$ parent ion is observed in both conformers while the product ion $\left[\mathrm{UbPd}_{2}+5 \mathrm{H}\right]^{9+}$ is observed primarily in only the elongated conformer. The question arises: Does $\left[\mathrm{UbPd}_{2}+5 \mathrm{H}\right]^{9+}$ originate only from the elongated conformer or also from the new partially folded conformer where the loss of en is accompanied by unfolding? The elongated $\left[\mathrm{UbPd}_{2}+5 \mathrm{H}\right]^{9+}$ was confirmed to derive from both parent conformers, by conducting the CID in the transfer T-wave cell after IM separation of only the parent conformers. Now two $\left[\mathrm{UbPd}_{2}+5 \mathrm{H}\right]^{9+}$ products of approximately equal intensity are observed time-aligned under both parent conformers, showing the product originates from both conformers (Figure S8). The same behavior is also exhibited by the $5+$ species where the new folded form loses en and forms a compact conformer. Conducting the same experiment but increasing the $\mathrm{CE}$ to $45 \mathrm{~V}$ lab, results in the two conformers dissociating into a similar pattern of product ions, most being identifiable $a, b, y$ and internal fragment ions as shown in Figure 6 and Table 2.

Table 2 shows that $\mathrm{Pd}^{2+}$ is binding, in both conformers, at the Met1 and Glu51/Asp52 sites. For example, $\left(b_{3}+\mathrm{Pd}\right)^{+}$, $\left(\mathrm{b}_{4}+\mathrm{Pd}\right)^{+},\left(\mathrm{b}_{11}+\mathrm{Pd}\right)^{2+}$, and $\left(\mathrm{a}_{1}+\mathrm{Pd}\right)^{+}$are evidence that the $\mathrm{Pd}^{2+}$ is anchored to the Metl site, although $\mathrm{b}_{2}{ }^{+}, \mathrm{b}_{3}{ }^{+}, \mathrm{b}_{4}{ }^{+}, \mathrm{b}_{5}{ }^{+}$, and $\mathrm{b}_{6}{ }^{+}$are also observed without $\mathrm{Pd}^{2+}$. The internal fragments $\left[\left(\mathrm{E}_{51}-\mathrm{D}_{52}\right)+\mathrm{Pd}\right]^{+}$and $\left[\left(\mathrm{E}_{51}-\mathrm{D}_{52}\right)+\mathrm{Pd}-\mathrm{CO}\right]^{+}$show that $\mathrm{Pd}^{2+}$ is attached to the Glu51-Asp52 sequence. The $\mathrm{y}_{13}{ }^{2+}$ ion is the main product from both conformers and suggests that His68 is not a preferred $\mathrm{Pd}^{2+}$ anchoring site, with both conformers also exhibiting a series of $\mathrm{y}_{9}{ }^{2+}$ to $\mathrm{y}_{18}{ }^{2+}$ ions. However, the ions $\left(\mathrm{y}_{58}+\mathrm{Pd}\right)^{6+},\left(\mathrm{y}_{16}+\mathrm{Pd}-\mathrm{H}_{2} \mathrm{O}\right)^{3+}$, and $\left(\mathrm{y}_{18}+\mathrm{Pd}\right)^{3+}$ do show Ub sequences that include both His68 and $\mathrm{Pd}^{2+}$. Structural rearrangement that accompanies the transfer of Pd-Ub from solution to the gas-phase and during the CID process may result with $\mathrm{Pd}^{2+}$ binding to sequences that are not necessarily the preferred anchor sites in solution but to binding sites that most effectively retain $\mathrm{Pd}^{2+}$ in the gas phase. Other ions that contain $\mathrm{Pd}^{2+}$ include the $\left[\left(\mathrm{I}_{3}-\mathrm{E}_{16}\right)+\mathrm{Pd}\right]^{2+}$ internal fragment that contains neither Met1, Glu51/Asp52 or His 68 but does contain Glu16, a site determined to be a potential oxygen donor ligand for $\mathrm{Cu}(\mathrm{II})$ anchored to the $\mathrm{N}$-terminus of $\mathrm{Ub}$ [21]. The $\left(\mathrm{b}_{63}+\mathrm{Pd}_{2}\right)^{7+}$ ion contains two $\mathrm{Pd}^{2+}$ with the potential binding sites of Met1, Glu16, and Glu51/Asp52 being contained in the sequence.

The $\left(\mathrm{b}_{4}+\mathrm{Pd}\right)^{+}$and $\left(\mathrm{b}_{3}+\mathrm{Pd}\right)^{+}$fragments are consistent with $\mathrm{Pd}^{2+}$ anchoring to the sulfur of methionine, and binding to neighboring amide nitrogen along the peptide backbone to form a stable polydentate complex, a similar mechanism to that described by Milović et al. [20]. However, the Nterminal and possibly the amide nitrogen in the side group of Gln2 are also potential $\mathrm{Pd}^{2+}$ binding sites. For instance, in the $\left(\mathrm{a}_{1}+\mathrm{Pd}\right)^{+}$product ion it seems likely that $\mathrm{Pd}^{2+}$ is bound to both the sulfur of Met1 and the N-terminus. The Met1 site in $\mathrm{Ub}$ is expected to be cleavage inactive because it lacks "upstream" amide groups [20]. The His68, however, is expected to be active but is dependent on $\mathrm{Pd}^{2+}$ anchoring to histidine and binding to the adjacent "upstream" nitrogen of the backbone amide group $[15,20]$. It is, therefore, surprising that there is not more clear evidence of $\mathrm{Pd}^{2+}$ binding to histidine from the IM-MS/MS and MS/MS studies.

\section{Conclusions}

The observed conformations of $\mathrm{Ub}$ are significantly affected by the binding of one to four $\mathrm{Pd}^{2+}$ or $\mathrm{Pd}(\mathrm{en})^{2+}$ to $\mathrm{Ub}$ and exhibit a new set of folded or partially folded conformers at

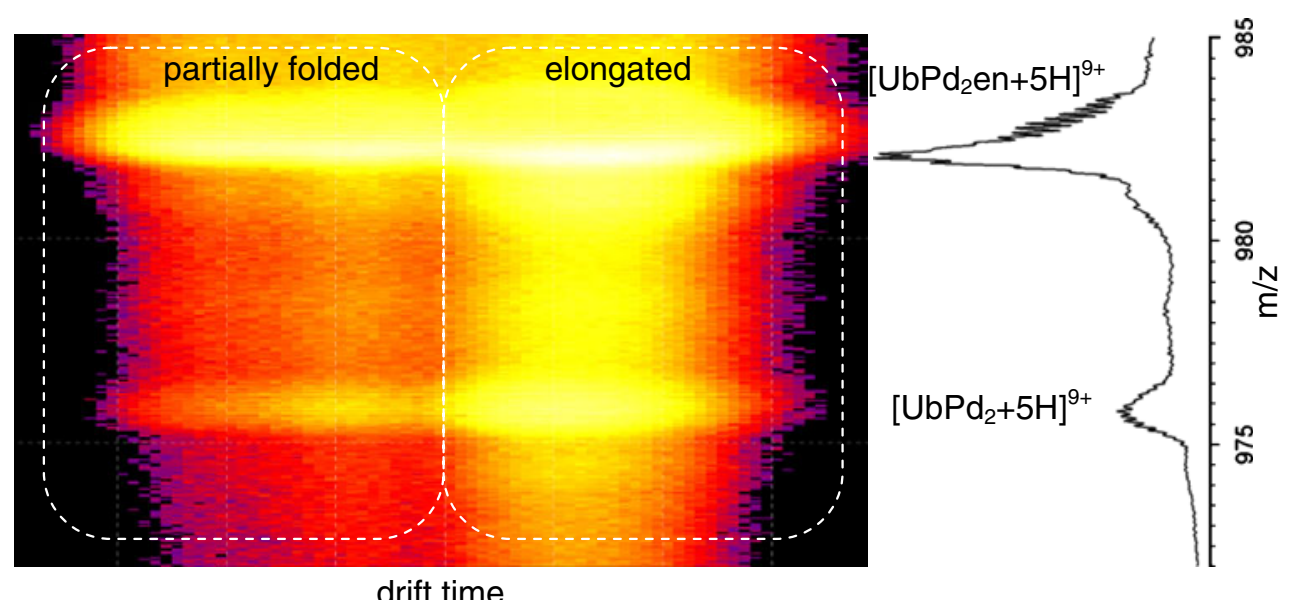

Figure 5. IM-MS/MS of the $\left[\mathrm{UbPd}_{2} \mathrm{en}+5 \mathrm{H}^{+}\right]^{9+}$ species in both the partially folded and elongated conformations using $25 \mathrm{~V}$ (labframe) in the trap T-wave cell. The formation of $\left[\mathrm{UbPd}_{2}+5 \mathrm{H}\right]^{9+}$ is observed in the elongated conformation 

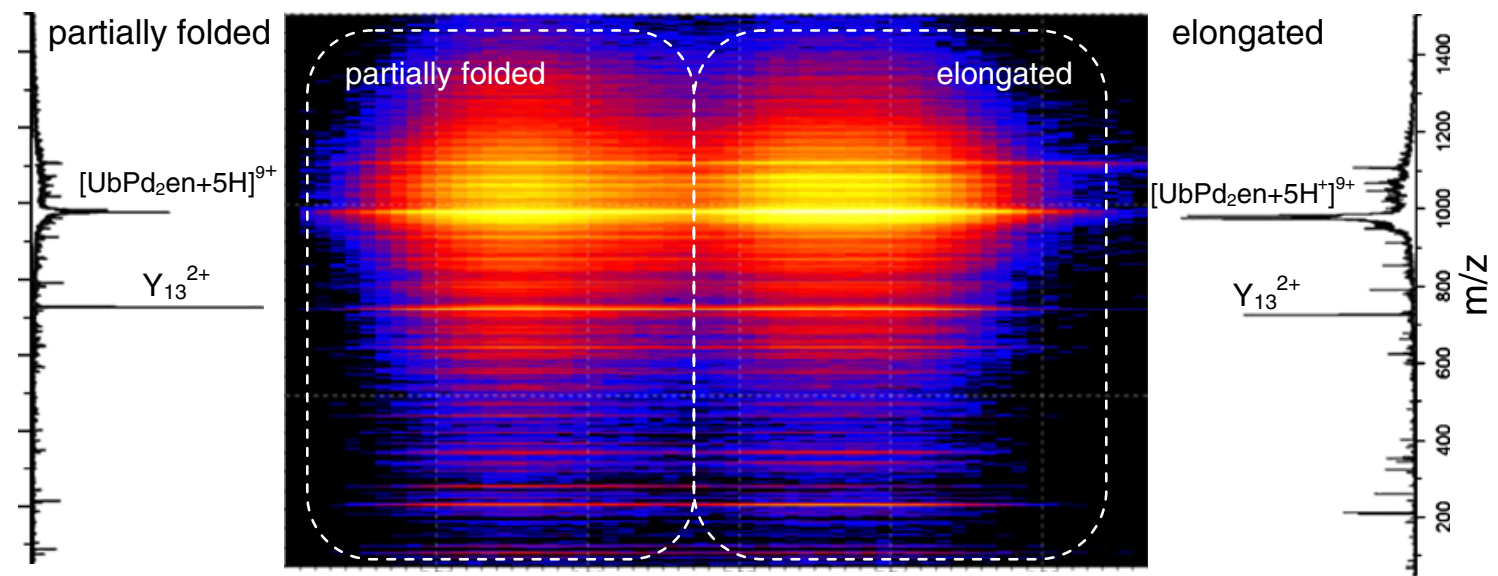

drift time

Figure 6. IM-MS/MS of the $\left[\mathrm{UbPd}_{2} \mathrm{en}+5 \mathrm{H}^{+}\right]^{9+}$ species using $45 \mathrm{~V}$ lab-frame applied at the transfer $\mathrm{T}$-wave cell. The result shows a series of product ions time-aligned with their parent conformer. The MS on either side of the driftscope plot show the extracted MS/MS data of the partially folded and elongated conformational states

Table 2. Products of the IM-MS/MS of $\left[\mathrm{UbPd}_{2}(\mathrm{en})+5 \mathrm{H}\right]^{9+}$ using $45 \mathrm{~V}$ collision energy in the transfer T-wave cell and sorted by intensity

\begin{tabular}{|c|c|c|c|c|c|c|c|}
\hline \multicolumn{4}{|c|}{ New conformer $\left[\mathrm{UbPd}_{2}(\mathrm{en})+5 \mathrm{H}\right]^{9+}$} & \multicolumn{4}{|c|}{ Elongated conformer $\left[\mathrm{UbPd}_{2}(\mathrm{en})+5 \mathrm{H}\right]^{9+}$} \\
\hline Assignment & Calculated & Observed & Int. $^{a}$ & Assignment & Calculated & Observed & Int. $^{a}$ \\
\hline $\mathrm{y}_{13}{ }^{2+}$ & 725.9 & 725.9 & 100 & $\mathrm{y}_{13}{ }^{2+}$ & 725.9 & 725.8 & 100 \\
\hline$\left(\mathrm{b}_{4}+\mathrm{Pd}\right)^{+}$ & 624.2 & 624.1 & 33.6 & $\left(a_{1}+P d\right)^{+}$ & 210.0 & 209.8 & 56.2 \\
\hline $\mathrm{b}_{2}^{+}$ & 260.1 & 260.0 & 29.3 & {$\left[\left(\mathrm{E}_{51}-\mathrm{D}_{52}\right)+\mathrm{Pd}\right]^{+}$} & 349.0 & 348.9 & 38.3 \\
\hline$\left(a_{1}+P d\right)^{+}$ & 210.0 & 209.8 & 29.3 & $\left(\mathrm{~b}_{4}+\mathrm{Pd}\right)^{+}$ & 624.2 & 624.1 & 33.2 \\
\hline$\left[\left(\mathrm{E}_{51}-\mathrm{D}_{52}\right)+\mathrm{Pd}\right]^{+}$ & 349.0 & 348.9 & 22.8 & {$\left[\left(\mathrm{E}_{51}-\mathrm{D}_{52}\right)+\mathrm{Pd}-\mathrm{CO}\right]^{+}$} & 321.0 & 320.9 & 23.2 \\
\hline $\mathrm{y}_{14}{ }^{2+}$ & 790.0 & 789.9 & 16.2 & $\left(\mathrm{y}_{58}+\mathrm{Pd}\right)^{6+}$ & 1106.9 & 1106.8 & 20.5 \\
\hline$\left(\mathrm{y}_{58}+\mathrm{Pd}\right)^{6+}$ & 1106.9 & 1106.8 & 16.2 & $\left(\mathrm{~b}_{63}+\mathrm{Pd}_{2}\right)^{7+}$ & 1046.9 & 1046.9 & 16.6 \\
\hline$\left[\left(\mathrm{E}_{51}-\mathrm{D}_{52}\right)+\mathrm{Pd}-\mathrm{CO}\right]^{+}$ & 321.0 & 320.9 & 16.0 & $\mathrm{y}_{14}{ }^{2+}$ & 790.0 & 789.9 & 16.2 \\
\hline $\mathrm{y}_{16}{ }^{2+}$ & 910.6 & 910.5 & 14.2 & $\mathrm{y}_{16}{ }^{2+}$ & 910.6 & 910.5 & 15.6 \\
\hline $\mathrm{y}_{8}{ }^{2+}$ & 442.3 & 442.2 & 13.6 & $\mathrm{~b}_{2}^{+}$ & 260.1 & 260.0 & 12.0 \\
\hline$\left(\mathrm{T}_{12}-\mathrm{P}_{19}\right)^{2+}$ & 442.2 & 442.2 & 13.6 & $\mathrm{y}_{15}{ }^{2+}$ & 854.0 & 853.9 & 11.8 \\
\hline $\mathrm{b}_{3}^{+}$ & 373.2 & 373.1 & 12.2 & $\left(b_{11}+P d\right)^{2+}$ & 676.3 & 676.2 & 11.6 \\
\hline $\mathrm{y}_{15}{ }^{2+}$ & 854.0 & 853.9 & 11.9 & $\mathrm{~b}_{18}{ }^{2+}$ & 1017.1 & 1017.0 & 7.7 \\
\hline $\mathrm{b}_{18}{ }^{2+}$ & 1017.1 & 1017.0 & 11.9 & $\left(\mathrm{y}_{18}+\mathrm{Pd}\right)^{3+}$ & 734.4 & 734.3 & 7.0 \\
\hline$\left(\mathrm{b}_{63}+\mathrm{Pd}_{2}\right)^{7+}$ & 1046.9 & 1046.9 & 11.5 & $\left(\mathrm{y}_{16}+\mathrm{Pd}-\mathrm{H}_{2} \mathrm{O}\right)^{3+}$ & 636.0 & 635.9 & 7.0 \\
\hline$y_{12}{ }^{2+}$ & 661.4 & 661.3 & 8.7 & $\left(b_{3}+P d\right)^{+}$ & 477.1 & 477.0 & 6.8 \\
\hline$b_{5}^{+}$ & 619.3 & 619.2 & 8.3 & {$\left[\left(\mathrm{I}_{3}-\mathrm{E}_{16}\right)+\mathrm{Pd}\right]^{2+}$} & 825.4 & 825.3 & 6.0 \\
\hline $\mathrm{y}_{11}^{2+}$ & 617.9 & 617.8 & 8.3 & $\mathrm{~b}_{3}^{+}$ & 373.2 & 373.1 & 5.5 \\
\hline$\left(b_{3}+P d\right)^{+}$ & 477.1 & 477.0 & 8.2 & $\mathrm{~b}_{5}^{+}$ & 619.3 & 619.2 & 5.5 \\
\hline$\left(\mathrm{b}_{11}+\mathrm{Pd}\right)^{2+}$ & 676.3 & 676.2 & 8.2 & $\mathrm{y}_{12}{ }^{2+}$ & 661.4 & 661.3 & 5.5 \\
\hline$\left[\left(\mathrm{I}_{3}-\mathrm{E}_{16}\right)+\mathrm{Pd}\right]^{2+}$ & 825.4 & 825.3 & 7.6 & $\mathrm{y}_{11}{ }^{2+}$ & 617.9 & 617.8 & 5.5 \\
\hline$\left(\mathrm{y}_{16}+\mathrm{Pd}-\mathrm{H}_{2} \mathrm{O}\right)^{3+}$ & 636.0 & 635.9 & 7.6 & $\mathrm{~b}_{41}{ }^{4+}$ & 913.7 & 913.6 & 5.1 \\
\hline $\mathrm{b}_{16}{ }^{2+}$ & 903.0 & 903.0 & 6.6 & $\left(\mathrm{~T}_{14}-\mathrm{E}_{18}\right)^{+}$ & 572.3 & 572.2 & 4.8 \\
\hline$\left(\mathrm{y}_{18}+\mathrm{Pd}\right)^{3+}$ & 734.4 & 734.3 & 6.6 & $\mathrm{y}_{5}^{+}$ & 558.4 & 558.2 & 3.6 \\
\hline $\mathrm{b}_{4}^{+}$ & 520.3 & 520.2 & 5.4 & $\mathrm{~b}_{4}^{+}$ & 520.3 & 520.1 & 3.5 \\
\hline$\left(\mathrm{T}_{14}-\mathrm{E}_{18}\right)^{+}$ & 572.3 & 572.2 & 5.1 & $\mathrm{~b}_{6}^{+}$ & 747.4 & 747.3 & 3.5 \\
\hline $\mathrm{y}_{10}{ }^{2+}$ & 567.4 & 567.3 & 4.9 & $\left(\mathrm{~V}_{5}-\mathrm{E}_{18}\right)^{2+}$ & 757.5 & 757.4 & 3.4 \\
\hline $\mathrm{b}_{41}{ }^{4+}$ & 913.7 & 913.6 & 4.9 & $\left(\mathrm{~L}_{15}-\mathrm{E}_{18}\right)^{+}$ & 471.3 & 471.1 & 3.4 \\
\hline $\mathrm{y}_{9}^{2+}$ & 510.8 & 510.7 & 4.8 & $\mathrm{~b}_{16}{ }^{2+}$ & 903.0 & 903.0 & 3.3 \\
\hline$\left(\mathrm{R}_{72}-\mathrm{G}_{75}\right)^{+}$ & 501.3 & 501.2 & 4.8 & $\mathrm{y}_{8}{ }^{2+}$ & 442.3 & 442.2 & 3.0 \\
\hline $\mathrm{b}_{11}^{+}$ & 1247.7 & 1247.7 & 4.2 & $\left(\mathrm{~V}_{5}-\mathrm{E}_{18}\right)^{+}$ & 1513.9 & 1513.9 & 2.6 \\
\hline$\left(\mathrm{L}_{15}-\mathrm{E}_{18}\right)^{+}$ & 471.3 & 471.1 & 4.1 & $\mathrm{y}_{10}{ }^{2+}$ & 567.4 & 567.3 & 2.3 \\
\hline$\left(\mathrm{V}_{5}-\mathrm{E}_{18}\right)^{+}$ & 1513.9 & 1513.9 & 3.6 & $\left(\mathrm{R}_{72}-\mathrm{G}_{75}\right)^{+}$ & 501.3 & 501.2 & 2.3 \\
\hline $\mathrm{b}_{6}^{+}$ & 747.4 & 747.4 & 3.5 & $\left(\mathrm{Q}_{2}-\mathrm{F}_{4}\right)^{+}$ & 389.2 & 389.1 & 2.2 \\
\hline$\left(\mathrm{V}_{5}-\mathrm{E}_{18}\right)^{2+}$ & 757.5 & 757.4 & 3.5 & $\left(\mathrm{Q}_{2}-\mathrm{V}_{5}\right)$ & 488.3 & 488.2 & 2.2 \\
\hline $\mathrm{y}_{5}^{+}$ & 558.4 & 558.2 & 3.0 & $\left(\mathrm{y}_{5}-\mathrm{H}_{2} \mathrm{O}\right)^{+}$ & 540.3 & 540.2 & 2.1 \\
\hline $\mathrm{y}_{18}{ }^{3+}$ & 700.1 & 700.0 & 2.5 & $\mathrm{y}_{18}{ }^{3+}$ & 700.1 & 700.0 & 2.0 \\
\hline$\left(V_{5}-V_{17}\right)^{+}$ & 1384.8 & 1384.8 & 2.3 & $\left(\mathrm{~V}_{5}-\mathrm{V}_{17}\right)^{+}$ & 1384.8 & 1384.8 & 1.9 \\
\hline
\end{tabular}

${ }^{\mathrm{a}}$ Intensity approximated by using the height of the tallest isotope peak of the product ion as a percentage of the height of the $\mathrm{y}_{13}{ }^{2+}$ peak 
each of the $4+$ to $10+$ charge states. These new Pd-Ub conformers exhibit less gas-phase unfolding than unbound $\mathrm{Ub}$ and are more stable if they contain at least one $\mathrm{Pd}^{2+}$ ion, rather than all $\operatorname{Pd}(\mathrm{en})^{2+}$. The folded and partially folded Pd$\mathrm{Ub}$ species lose the en ligand at low collision energies and unfold into the compact or elongated conformer, respectively. At higher collision energies, IM-MS/MS analysis shows that Met1 and Glu51/Asp52 are the preferred binding sites for $\mathrm{Pd}^{2+}$ and also show $\mathrm{Pd}^{2+}$ possibly binding to Glu16 and His68 sites. However, many of the CID fragment ions show the same $\mathrm{Ub}$ sequence with and without $\mathrm{Pd}^{2+}$, for example $\mathrm{b}_{4}{ }^{+}$and $\left(\mathrm{b}_{4}+\mathrm{Pd}\right)^{+}$and the $\mathrm{y}_{18}{ }^{3+}$ and $\left(\mathrm{y}_{18}+\mathrm{Pd}\right)^{3+}$ ions. An explanation is that structural rearrangement accompanying Pd-Ub transfer from solution to the gas phase and the CID process results with $\mathrm{Pd}^{2+}$ remaining attached to sequences that are not necessarily the preferred anchor sites in solution but to binding sites that effectively retain $\mathrm{Pd}^{2+}$ in the gas phase. The study suggests $\mathrm{Pd}^{2+}$ is stabilizing the new conformers through binding across different local regions of $\mathrm{Ub}$ and helping to retain the folded structure. Therefore, the folded $\mathrm{Ub}$ conformer may be promoting simultaneous binding of $\mathrm{Pd}^{2+}$ ion to multiple side groups of Met1, Glu51, and Asp52. This type of sequestering of $\mathrm{Pd}^{2+}$ will reduce the efficiency of $\mathrm{Pd}^{2+}$ ions to selectively cleave $\mathrm{Ub}$ because it prevents the formation of an activated Pd-Ub complex necessary for backbone cleavage. Previous work $[15,16]$ has shown that specific peptide bond cleavage requires $\mathrm{Pd}^{2+}$ to anchor to either the Met or His side group and to an adjacent backbone amide nitrogen atom before peptide bond hydrolysis can occur.

\section{Acknowledgments}

The authors thank the Office of Graduate Studies and Research at Texas A\&M University-Commerce for financial support through the faculty enhancement grant, the NSF-MRI grant 0821247 for instrument support, NSF-REU grant 0851966 for W.B., the NSF S-STEM grant 0807190 for V.G., and the Welch Foundation grant T-0014 for S.K. They also thank Dr. Nenad Kostić and Porntip Leeprapaiwong for preparation of the Pd-Ub sample.

\section{References}

1. Bellotti, V., Stoppini, M.: Protein misfolding diseases. Open. Biol. J. 2, 228-234 (2009)

2. Dobson, C.M.: Protein folding and misfolding. Nature 426, 884-890 (2003)

3. Hershko, A., Ciechanover, A.: The ubiquitin system. Annu. Rev. Biochem. 67, 425-479 (1998)

4. Bohrer, B.C., Merenbloom, S.I., Koeniger, S.L., Hilderbrand, A.E., Clemmer, D.E.: Biomolecule analysis by ion mobility spectrometry. Annu. Rev. Anal. Chem. 1, 293-327 (2008)

5. Uetrecht, C., Rose, R.J., van Duijn, E., Lorenzen, K., Heck, A.J.R.: Ion mobility mass spectrometry of proteins and protein assemblies. Chem. Soc. Rev. 39, 1633-1655 (2010)

6. Pringle, S.D., Giles, K., Wildgoose, J.L., Williams, J.P., Slade, S.E., Thalassinos, K., Batemann, R.H., Bowers, M.T., Scrivens, J.H.: An investigation of the mobility separation of some peptide and protein ions using a new hybrid quadrupole/traveling wave IMS/oa-TOF instrument. Int. J. Mass Spectrom. 261, 1-12 (2007)
7. Smith, D.P., Giles, K., Bateman, R.H., Radford, S.E., Ashcroft, A.E.: Monitoring co-populated conformational states during protein folding events using electrospray ionization-ion mobility spectrometry-mass spectrometry. J. Am. Soc. Mass Spectrom. 18, 2180-2190 (2007)

8. Benesch, J.L.P.: Collisional activation of protein complexes: picking up the pieces. J. Am. Soc. Mass Spectrom. 20, 341-348 (2009)

9. Hopper, J.T.S., Oldham, N.J.: Collision induced unfolding of protein ions in the gas phase studied by ion mobility-mass spectrometry: the effect of ligand binding on conformational stability. J. Am. Soc. Mass Spectrom. 20, 1851-1858 (2009)

10. Smith, D.P., Knapman, T.W., Campuzano, I., Malham, R.W., Berryman, J.T., Radford, S.E., Ashcroft, A.E.: Deciphering drift time measurements from traveling wave ion mobility spectrometry-mass spectrometry studies. Eur. J. Mass Spectrom. 15, 113-130 (2009)

11. Scarff, C.A., Thalassinos, K., Hilton, I., Scrivens, J.H.: Traveling wave ion mobility mass spectrometry studies of protein structure: biological significance and comparison with x-ray crystallography and nuclear magnetic resonance spectroscopy measurements. Rapid Commun. Mass Spectrom. 22, 3297-3304 (2008)

12. Thalassinos, K., Grabenauer, M., Slade, S.E., Hilton, G.R., Bowers, M. T., Scrivens, J.H.: Characterization of phosphorylated peptides using traveling wave-based and drift cell ion mobility mass spectrometry. Anal. Chem. 81, 248-254 (2009)

13. Hilton, G.R., Thalassinos, K., Grabenauer, M., Sanghera, N., Slade, S. E., Wytennbach, T., Robinson, P.J., Pinheiro, T.J.T., Bowers, M.T., Scrivens, J.H.: Structural analysis of prion proteins by means of drift cell and traveling wave ion mobility mass spectrometry. J. Am. Soc. Mass Spectrom. 5, 845-854 (2010)

14. Williams, J.P., Lough, J.A., Campuzano, I., Richardson, K., Sadler, P. J.: Use of ion mobility mass spectrometry and a collision cross-section algorithm to study an organometallic ruthenium anticancer complex and its adducts with a DNA oligonucleotide. Rapid Commun. Mass Spectrom. 23, 3563-3569 (2009)

15. Milović, N.M., Kostić, N.M.: Palladium(II) complexes, as synthetic peptidases, regioselectively cleave the second peptide bond "upstream" from methionine and histidine side chains. J. Am. Chem. Soc. 124, 4759-4769 (2002)

16. Milović, N.M., Kostić, N.M.: Palladium(II) complex as a sequencespecific peptidase: hydrolytic cleavage under mild conditions of x-pro peptide bonds in x-pro-met and x-pro-his segments. J. Am. Chem. Soc. 125, 781-788 (2003)

17. Ahrends, R., Pieper, S., Neumann, B., Scheler, C., Linscheld, M.W.: Metal-coded affinity tag labeling: a demonstration of analytical robustness and suitability for biological applications. Anal. Chem. 81, 21762184 (2009)

18. Zhu, L., Kostić, N.M.: Sequence-dependent cleavage of albumins with palladium(II) complexes: role of serine residue in controlling the high regioselectivity of protein cleavage. Inorg. Chim. Acta 339, 104-110 (2002)

19. hu, L., Bakhtiar, R., Kostić, N.M.: Transition-metal complexes as alternatives to proteolytic enzymes. regioselective cleavage of myoglobin by palladium(II) aqua complexes. J. Biol. Inorg. Chem. 3, 383-391 (1998)

20. Milović, N.M., Kostić, N.M.: Interplay of terminal amino group and coordinating side chains in directing regioselective cleavage of natural peptides and proteins with palladium(II) complexes. Inorg. Chem. 41, 7053-7063 (2002)

21. Milardi, D., Arnesano, F., Grasso, G., Magri, A., Tabbi, G., Scintilla, S., Natile, G., Rizzarelli, E.: Ubiquitin stability and the Lys63-linked polyubiquitination site are compromised on copper binding. Angew. Chem. Int. Ed. 46, 7993-7995 (2007)

22. Vijay-Kumar, S., Bugg, C.E., Cook, W.J.: Structure of ubiquitin refined at $1.8 \AA$ A resolution. J. Mol. Biol. 194, 531-544 (1987)

23. Falini, G., Fermani, S., Tosi, G., Arnesano, F., Natile, G.: Structural probing of $\mathrm{Zn}(\mathrm{II}), \mathrm{Cd}(\mathrm{II})$, and $\mathrm{Hg}$ (II) binding to human ubiquitin. Chem. Commun. 45, 5960-5962 (2008)

24. Hoaglund, C.S., Valentine, S.J., Sporleder, C.R., Reilly, J.P., Clemmer, D.E.: Three-dimensional ion mobility TOFMS analysis of electrosprayed biomolecules. Anal. Chem. 70, 2236-2242 (1998)

25. Valentine, S.J., Counterman, A.E., Clemmer, D.E.: Conformer-dependent proton-transfer reactions of ubiquitin ions. J. Am. Soc. Mass Spectrom. 8, 954-961 (1997)

26. Clemmer, D. E. http://www.indiana.edu/ clemmer/Research/research.htm

27. Koeniger, S.L., Clemmer, D.E.: Resolution and structural transitions of elongated states of ubiquitin. J. Am. Soc. Mass Spectrom. 18, 322-331 (2007) 
28. Koeniger, S.L., Merenbloom, S.I., Clemmer, D.E.: Evidence for many resolvable structures within conformational types of electrosprayed ubiquitin ions. J. Phys. Chem. B 110, 7017-7021 (2006)

29. Koeniger, S.L., Merenbloom, S.I., Sundarapandian, S., Clemmer, D.E.: Transfer of structural elements from compact to extended states in unsolvated ubiquitin. J. Am. Chem. Soc. 128, 11713-11719 (2006)

30. Purves, R.W., Barnett, D.A., Ells, B., Guevremont, R.: Investigation of bovine ubiquitin conformers separated by high-field asymmetric waveform ion mobility spectrometry: cross section measurements using energy-loss experiments with a triple quadrupole mass spectrometer. $J$. Am. Soc. Mass Spectrom. 11, 738-745 (2000)

31. Robinson, E.W., Leib, R.D., Williams, E.R.: The role of conformation on electron capture dissociation of ubiquitin. J. Am. Soc. Mass Spectrom. 17, 1469-1479 (2006)
32. Hong, J., Miao, R., Zhao, C., Jiang, J., Tang, H., Zhu, L.: Mass spectrometry assisted assignments of binding and cleavage sites of copper(II) and platinum(II) complexes towards oxidized insulin B chain. J. Mass Spectrom. 41, 1061-1072 (2006)

33. Basolo, F., Bailar Jr., J.C., Tarr, B.R.: The stereochemistry of complex inorganic compounds. X. The stereoisomers of dichlorobis(ethylenediamine)platinum(IV) chloride. J. Am. Chem. Soc. 72, 2433-2438 (1950)

34. Heneghan, L.F., Bailar Jr., J.C.: The stereoisomerism of complex inorganic compounds. XVI. The stereoisomers of dichlorobis(ethylenediamine)platinum(IV) salts. J. Am. Chem. Soc. 75, 1840-1841 (1953)

35. Broennum, B., Johansen, H.S., Skibsted, L.H.: Ammine ligand exchange in tetra-amminepalladium(II) in aqueous solution. Acta Chem. Scand. 43, 975-980 (1989) 